\title{
Effect of $\alpha$-linolenic acid and DHA intake on lipogenesis and gene expression involved in fatty acid metabolism in growing-finishing pigs
}

\author{
A. De Tonnac ${ }^{1,2}$, E. Labussière ${ }^{1,2 *}$, A. Vincent ${ }^{1,2}$ and J. Mourot ${ }^{1,2}$ \\ ${ }^{1}$ INRA, UMR1348 PEGASE, 35590 Saint-Gilles, France \\ ${ }^{2}$ Agrocampus Ouest, UMR1348 PEGASE, 35000 Rennes, France \\ (Submitted 22 January 2016 - Final revision received 3 March 2016 - Accepted 10 March 2016 - First published online 16 May 2016)
}

\section{Abstract}

The regulation of lipogenesis mechanisms related to consumption of $n-3$ PUFA is poorly understood. The aim of the present study was to find out whether $\alpha$-linolenic acid (ALA) or DHA uptake can have an effect on activities and gene expressions of enzymes involved in lipid metabolism in the liver, subcutaneous adipose tissue and longissimus dorsi (LD) muscle of growing-finishing pigs. Six groups of ten pigs received one of six experimental diets supplemented with rapeseed oil in the control diet, extruded linseed, microalgae or a mixture of both to implement different levels of ALA and DHA with the same content in total $n$ - 3 . Results were analysed for linear and quadratic effects of DHA intake. The results showed that activities of malic enzyme (ME) and fatty acid synthase (FAS) decreased linearly in the liver with dietary DHA. Although the expression of the genes of these enzymes and their activities were poorly correlated, $M E$ and $F A S$ expressions also decreased linearly with DHA intake. The intake of DHA down-regulates the expressions of other genes involved in fatty acid (FA) metabolism in some tissues of pigs, such as fatty acid desaturase 2 and sterol-regulatory element binding transcription factor 1 in the liver and 2,4-dienoyl CoA reductase 2 in the LD muscle. FA oxidation in the LD muscle and FA synthesis decreased in the liver with increasing amount of dietary DHA, whereas a retroconversion of DHA into EPA seems to be set up in this last tissue.

Key words: Linolenic acid: DHA: Pigs: Lipogenic enzymes

In mammals, malic enzyme (ME) and glucose-6-phosphate dehydrogenase (G6PDH) are the main enzymes involved in supplying $\mathrm{NADPH}_{2}$ for the first step of lipid synthesis ${ }^{(1)}$. Subsequently, $\mathrm{NADPH}_{2}$ is used by fatty acid synthase (FAS) in order to synthesise palmitic acid from malonyl CoA. However, pigs are unable to synthesise the precursor of long-chain PUFA from palmitic acid because they are deficient in $\Delta 12$ and $\Delta 15$ desaturases $^{(2)}$. The precursor of PUFA $n$ - 3 named $\alpha$-linolenic acid (ALA) must be provided to animals in their feed in order to synthesise the main fatty acids (FA) of the $n-3$ family. These are EPA and DHA, which are synthesised from a sequence of desaturations with $\Delta 6$-desaturase and $\Delta 5$-desaturase and elongations with elongases. This latter step essentially takes place in the liver. However, it has been shown that feeding animals with different dietary FA has an effect on the gene expressions and activities of the key enzymes involved, first, in lipogenesis and, second, in de novo synthesis of long-chain FA. Indeed, PUFA n-6 promotes lipogenic activity in the subcutaneous adipose tissue (SCAT) of pigs ${ }^{(3,4)}$ or rats $^{(5)}$. Likewise, a diet containing $n$-3 FA increases FAS activity in SCAT, whereas ME activity is decreased in the liver and adipose tissue of pigs ${ }^{(6)}$. The results of the studies that were conducted on the effect of dietary $n-3$ FA on the gene expressions of lipogenic enzymes are in contrast, even if it was demonstrated that the response is tissue specific. Indeed, Duran-Montge et al $^{(7)}$ found that FAS expression decreased in the liver and the SCAT of pigs, respectively, with a supply of fish oil or linseed oil, whereas Meadus et al. ${ }^{(8)}$ found that FAS expression increased in the liver and muscle with a supply of DHA in the diet. Benitez et al. ${ }^{(9)}$ showed that $M E$ expression decreased in the liver of pigs when animals were fed PUFA such as C18:2n-6 and C18:3n-3, whereas its expression was not modified in the muscle and SCAT. Regarding the expressions of genes encoding for the enzymes involved in long-chain FA synthesis, it was shown that a supply of $n-3$ or $n-6$ FA in the diet decreased mRNA abundance of $\Delta 6$-desaturase and $\Delta 5$-desaturase in the liver of mammals ${ }^{(10,11)}$ and increased the transcript level of elongation of very long-chain FA 2 (ELOVL2) but not ELOVL5 corresponding to the elongases $^{(12)}$. In contrast, an $n$-3-deficient diet increased the mRNA levels of $\Delta 6$-desaturase and $\Delta 5$-desaturase in the liver of rats ${ }^{(13)}$. Finally, according to the source of the long-chain FA that is ingested by animals, the effect on the gene expressions and activities of enzymes involved in lipid metabolism is different.

Abbreviations: ALA, $\alpha$-linolenic acid; CON, control diet; DECR2, 2,4-dienoyl CoA reductase 2; ELOVL, elongation of very long chain fatty acid 5; FA, fatty acid; FADS2, fatty acid desaturase 2; FAS, fatty acid synthase; G6PDH, glucose-6-phosphate dehydrogenase; LD, longissimus dorsi; LPL, lipoprotein lipase; ME, malic enzyme; RXR $\alpha$, retinoid X receptor alpha; SCAT, subcutaneous adipose tissue; SREBP1, sterol-regulatory element binding transcription factor 1.

* Corresponding author: E. Labussière, email etienne.labussiere@rennes.inra.fr 
The aim of this study was to determine whether PUFA $n-3$ supplementation of the diet has an effect on lipogenic activities and expressions of the genes involved in PUFA synthesis and other lipid metabolism in growing-finishing pigs. In addition, the effect of varying composition of PUFA $n-3$ supplementation was assessed through different ALA:DHA ratios.

\section{Methods}

Animals were raised and slaughtered at Saint-Gilles INRA experimental site according to a protocol in accordance with the French legislation, and all procedures were conducted under the responsibility of J. M., approval number 04738.

\section{Animals and diets}

In total, thirty castrated male and thirty female cross-breed pigs ((Large white $\times$ Landrace) sows $\times$ Pietrain boar) with initial body weight (BW) of 64.6 (SEM 5.5$) \mathrm{kg}$ were raised from 16 to 24 weeks of age. All animals received feed and water ad libitum in individual crates with concrete floor.

Five pigs from each sex were assigned to one of six diets according to their initial BW. All diets contained $4 \%$ of fat and were supplemented with wheat bran to be isoenergetic on a net energy basis $^{(14)}$ (Table 1). Diets followed nutritional recommendations for pigs, so that the amino acid content was not a limiting factor for growth. The FA composition of the diets varied in order to implement different levels of ALA and DHA, which was achieved by the differential inclusion of extruded linseed (EL; Tradilin ${ }^{\circledR}$, Valorex) or microalgae (MA) (Schizochytrium sp. DHA Gold ${ }^{\circledR}$; DSM). Animals of the first diet, which served as control (CON), did not receive ALA and DHA. Two groups of animals received either $100 \%$ of ALA (diet ALA) or $100 \%$ of DHA (diet DHA). Others three groups of animals were fed mixtures of ALA and DHA (diets 2ALA/1DHA, ALA/DHA, 1ALA/2DHA). According to the experimental design, dietary ALA and DHA contents varied consistently with inclusion level of EL and MA. The ALA concentration decreased in the diets from 29.2 to $2.7 \%$ of total FA, and DHA increased from 0 to $19.9 \%$ of total FA (Table 1). All the diets were supplemented with 80 parts per million vitamin E to prevent PUFA oxidation. Feed consumption per animal was measured twice a week throughout the rearing phase by subtracting feed refusal from distributed feed quantities. Animals were weighed once a week, in the morning and before feed distribution.

\section{Slaughter and carcass measurements}

The pigs were fasted for $16 \mathrm{~h}$ before slaughter. They were stunned by electronarcosis before slaughter by bleeding at 114.9 (SEM 6.9) $\mathrm{kg}$ of BW on average. After evisceration, the liver, heart and kidney were removed from the carcass and weighed. Subsequently, the carcass was split into two parts and weighed in order to obtain total hot weight. The point of the second liver lobe was sampled. The longissimus dorsi (LD) and SCAT were sampled at the level of the third last rib on the right side of the carcass. Tissue samples were individually packed and frozen at $-20^{\circ} \mathrm{C}$ until analyses of FA composition. For enzyme activity and PCR analyses, samples were cut into small pieces, snap-frozen in liquid $\mathrm{N}_{2}$ and stored at $-80^{\circ} \mathrm{C}$. Carcasses were cooled at $1{ }^{\circ} \mathrm{C}$ for $24 \mathrm{~h}$ and then the $\mathrm{pH}$ was measured on LD muscle with a mobile pH-meter (Metrohm 826) at the level of the third last rib. Meat colour (1, a and b parameters) of LD was evaluated using a calibrated colorimeter (CR 300; Konica Minolta). The entire LD muscle and SCAT were collected to estimate their total weight in the carcass.

\section{Chemical analyses}

Diets were analysed based on feed samples obtained after manufacturing. The DM of the diets was measured according to AFNOR NF V 18-109 (October 1982) method ${ }^{(15)}$, the amount of crude protein according to NF ISO 16634-1 (December 2008) and Dumas principle ${ }^{(16)}$, and crude energy was measured in an adiabatic calorimeter according to the ISO 9831:1998 method $^{(17)}$ (Table 1).

Lipids were cold-extracted from $10 \mathrm{~g}$ of $\mathrm{LD}, 5 \mathrm{~g}$ of feed sample and liver and $1 \mathrm{~g}$ of SCAT. The weight of the test sample was determined from previous experiences to be representative of the sample taken from the animal and to obtain at least $15 \mathrm{mg}$ of fat for further assays. Samples of diets and LD were ground twice, especially with a Retsch DR100 equipped with a 1-mm mesh for diets and a Retsch Grindomix GM200 for LD. Samples of diets and tissues were then ground using a Polytron grinder equipped with a spindle (Kinematica) before extraction using chloroform-methanol $(2: 1, \mathrm{v} / \mathrm{v})^{(18)}$. FA methyl esters were saponified with methanolic sodium hydroxide solution in the presence of $\mathrm{C} 17$ :0 (margaric acid) as the internal FA standard. Next, they were methylated with boron trifluoride ${ }^{(19)}$. FA methyl esters were recovered using pentane plus distilled water solution and analysed by GC (Agilent Technologies 7890 GC system). The chromatograph was equipped with a capillary column of $0.25 \mathrm{~mm} \times 30 \mathrm{~m}$ polysiloxane polymer filled with dimethylpolysiloxane and 50\% cyanopropylphenyl in stationary phase. Temperature programme was initiated at $150^{\circ} \mathrm{C}$ and increased by $4{ }^{\circ} \mathrm{C} / \mathrm{min}$ up to $220^{\circ} \mathrm{C}$. The temperature was maintained at $220^{\circ} \mathrm{C}$ for $10.5 \mathrm{~min}$. Injector and flame ionisation detector temperatures were kept constant at 220 and $280^{\circ} \mathrm{C}$, respectively. Hydrogen was used as the carrier gas. Retention times and peaks were determined using chromatography software ChemStation Agilent. The identity of the peaks was verified by comparison with the retention time of standard FA methyl esters. Results were expressed as the percentage of total FA in diets and in mg per $100 \mathrm{~g}$ of tissue.

\section{Enzyme activities}

Depending on the concentrations of FAS, ME and G6PDH enzymes and activities in the tissues, dosages were assessed in $0.4 \mathrm{~g}$ of non-crushed backfat or liver and in $1.2 \mathrm{~g}$ of non-crushed LD muscle diluted in homogenisation buffer containing 0.25 M-ice-cold sucrose solution, EDTA ( $1 \mathrm{~mm}$ ) and DTT ( $1 \mathrm{~mm}$ ). Mixtures were ultracentrifuged at $100000 \mathrm{~g}$ for $1 \mathrm{~h}$ at $4^{\circ} \mathrm{C}$. The supernatant containing enzymes was aliquoted and stored at $-80^{\circ} \mathrm{C}$ before being analysed. The activity of enzymes was 
Table 1. Ingredients and chemical composition of the diets

\begin{tabular}{|c|c|c|c|c|c|c|}
\hline$\%$ & CON & ALA & 2ALA/1DHA & ALA/DHA & 1ALA/2DHA & $\mathrm{DHA}$ \\
\hline \multicolumn{7}{|l|}{ Ingredient composition } \\
\hline Wheat & 25.953 & 24.581 & 24.879 & $25 \cdot 170$ & $25 \cdot 454$ & $25 \cdot 715$ \\
\hline Maize & $15 \cdot 849$ & $15 \cdot 011$ & $15 \cdot 193$ & $15 \cdot 371$ & $15 \cdot 545$ & $15 \cdot 704$ \\
\hline Barley & $25 \cdot 308$ & 23.970 & $24 \cdot 261$ & 24.544 & 24.822 & 25.076 \\
\hline Wheat bran & 5.923 & 4.977 & 4.943 & 4.909 & 4.876 & 4.907 \\
\hline Soyabean meal & $18 \cdot 821$ & $17 \cdot 826$ & 18.042 & $18 \cdot 253$ & 18.459 & 18.648 \\
\hline Rapeseed oil & $1 \cdot 750$ & - & - & - & - & - \\
\hline Extruded linseed & - & $7 \cdot 570$ & $5 \cdot 610$ & 3.700 & 1.830 & - \\
\hline Microalgae & - & - & 0.940 & $1 \cdot 850$ & $2 \cdot 740$ & 3.610 \\
\hline Molasses & 2.972 & $2 \cdot 815$ & $2 \cdot 849$ & $2 \cdot 882$ & 2.915 & 2.944 \\
\hline Calcium carbonate & $1 \cdot 274$ & $1 \cdot 207$ & $1 \cdot 221$ & $1 \cdot 235$ & $1 \cdot 249$ & $1 \cdot 262$ \\
\hline Dicalcium phosphate & 0.495 & 0.469 & 0.475 & 0.480 & 0.486 & 0.491 \\
\hline Salt & 0.446 & 0.422 & 0.427 & 0.432 & 0.437 & 0.442 \\
\hline L-Lysine-HCl & 0.330 & 0.312 & 0.316 & 0.320 & 0.324 & 0.327 \\
\hline DL-Methionine & 0.042 & 0.039 & 0.040 & 0.040 & 0.041 & 0.041 \\
\hline L-Threonine & 0.030 & 0.028 & 0.028 & 0.029 & 0.029 & 0.029 \\
\hline Vitamins, minerals and additives & 0.804 & 0.772 & 0.779 & 0.786 & 0.793 & 0.799 \\
\hline \multicolumn{7}{|l|}{ Chemical composition } \\
\hline DM (\%) & 88.05 & 88.06 & $88 \cdot 32$ & 88.00 & $87 \cdot 12$ & $88 \cdot 34$ \\
\hline Gross energy (MJ/kg of DM) & $14 \cdot 40$ & $14 \cdot 48$ & 14.59 & 14.48 & $14 \cdot 39$ & 14.52 \\
\hline Crude protein (\% of DM) & $17 \cdot 77$ & $17 \cdot 12$ & $16 \cdot 89$ & $16 \cdot 13$ & $16 \cdot 25$ & $16 \cdot 38$ \\
\hline Fat $(\%$ of $D M)$ & $3 \cdot 72$ & 3.85 & $3 \cdot 79$ & 3.64 & 3.68 & 3.50 \\
\hline \multicolumn{7}{|l|}{ Fatty acids ( $\%$ of total fatty acids) } \\
\hline C16:0 & $13 \cdot 04$ & $12 \cdot 67$ & $14 \cdot 69$ & $16 \cdot 58$ & $18 \cdot 63$ & 20.89 \\
\hline C18:0 & $2 \cdot 28$ & 3.00 & 2.67 & $2 \cdot 27$ & 1.92 & 1.66 \\
\hline C18: $1 n-9 c$ & $37 \cdot 08$ & $18 \cdot 65$ & $16 \cdot 67$ & $14 \cdot 75$ & $12 \cdot 72$ & 11.01 \\
\hline C18:2n-6c & $36 \cdot 64$ & $34 \cdot 27$ & $32 \cdot 11$ & 30.96 & $29 \cdot 24$ & $27 \cdot 32$ \\
\hline C18:3n-3 & $6 \cdot 60$ & $29 \cdot 19$ & $22 \cdot 68$ & $16 \cdot 13$ & $9 \cdot 21$ & 2.69 \\
\hline $\mathrm{C} 22: 6 n-3$ & 0.00 & 0.00 & $5 \cdot 26$ & $10 \cdot 07$ & $15 \cdot 28$ & 19.90 \\
\hline SFA & $16 \cdot 24$ & $16 \cdot 35$ & $19 \cdot 10$ & $21 \cdot 60$ & $24 \cdot 38$ & $27 \cdot 50$ \\
\hline MUFA & $40 \cdot 41$ & $20 \cdot 07$ & $18 \cdot 15$ & $16 \cdot 09$ & $14 \cdot 12$ & $12 \cdot 34$ \\
\hline PUFA & 43.35 & 63.57 & $62 \cdot 75$ & $62 \cdot 30$ & 61.50 & $60 \cdot 16$ \\
\hline$n-6$ & $36 \cdot 64$ & $34 \cdot 27$ & 34.43 & 35.42 & $36 \cdot 01$ & $36 \cdot 25$ \\
\hline$n-3$ & $6 \cdot 64$ & $29 \cdot 24$ & $28 \cdot 27$ & $26 \cdot 83$ & $25 \cdot 44$ & 23.83 \\
\hline$n-6: n-3$ & 5.52 & $1 \cdot 17$ & $1 \cdot 22$ & $1 \cdot 32$ & 1.42 & 1.52 \\
\hline
\end{tabular}

CON, control diet; ALA, a-linolenic acid; 2ALA/1DHA, diet containing $75 \%$ of EL and $25 \%$ of microalgae (MA); ALA/DHA, diet containing $50 \%$ of EL and $50 \%$ of MA; $1 \mathrm{ALA} / 2 \mathrm{DHA}$, diet containing $25 \%$ of EL and $75 \%$ of MA; DHA, diet containing MA.

determined by spectrometry at $340 \mathrm{~nm}$ absorbance ${ }^{(20)}$ using a KoneLab 20i apparatus (Thermo Scientific). Activities were expressed in nanomoles of NADPH formed per minute and per gram of tissue for ME and G6PDH and in nanomoles of NADP formed per minute and per gram of tissue for FAS.

\section{Total RNA extraction and complementary DNA synthesis}

For total RNA extraction, samples of frozen SCAT, LD muscle or liver $\left(80-120 \mathrm{mg}\right.$ ) were homogenised in TRIZOL ${ }^{\circledR}$ reagent (Invitrogen) using Precellys homogenizer (Ozyme) and treated according to the manufacturer's instructions. Next, RNA was purified using silica-membrane technology (NucleoSpin RNA II kit; Macherey-Nagel) and quantified using a NanoDrop ND-1000 spectrophotometer (Thermo Scientific). The integrity of total RNA was assessed using the Agilent RNA 6000 Nano kit with an Agilent 2100 Bioanalyzer (Agilent Technologies). For later analyses, RNA with RNA Integrity number $>5 \cdot 1$; A260:280 ratio $>2 \cdot 0$ and A260:230 ratio $>1.0$ were considered. Complementary DNA (cDNA) was synthetised using the high-capacity RNA-to-cDNA kit (Applied Biosystems) in $20 \mu$ total reaction volume including $1 \mu \mathrm{g}$ total RNA, $1 \times$ RT buffer and $1 \times$ RT enzyme mix at $37^{\circ} \mathrm{C}$ for $60 \mathrm{~min}$. The reaction was terminated at $95^{\circ} \mathrm{C}$ for $5 \mathrm{~min}$.

\section{Quantitative real-time PCR}

The expressions of twenty-seven target genes and three reference genes were measured by PCR in the three tissues (Table 2). Primers were designed from porcine sequences with Primer Express ${ }^{\circledR}$ software 3.0 (Applied Biosystems) (Table 2).

For each primer pair, the amplification efficiency of quantitative real-time PCR (qPCR) reaction was determined using calibration curves generated with six decreasing cDNA concentrations of a pool of samples ( 10 to $10 \mathrm{E}^{-03} \mathrm{ng} \mathrm{RNA}$ ). The efficiency was calculated using Data Analysis Gene Expression

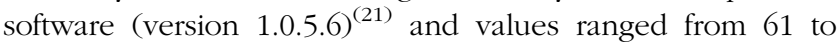
$124 \%$. For all samples, amplification reaction was performed in duplicate in $10 \mu \mathrm{l}$ with $2 \mathrm{ng}$ of reverse-transcribed RNA, both forward and reverse primers (200 nM) in 1X PCR buffer (Fast SYBRGreen ${ }^{\circledR}$ Mastermix; Applied Biosystem) containing Uracil DNA glycosylase to prevent any DNA contamination in a 7900HT Fast Real-Time PCR System (Appied Biosystems). Thermal cycling conditions were as follows: $50^{\circ} \mathrm{C}$ during $2 \mathrm{~min}$, $95^{\circ} \mathrm{C}$ during $20 \mathrm{~s}$, followed by forty cycles of denaturation at $95^{\circ} \mathrm{C}$ during $3 \mathrm{~s}$ and annealing at $60^{\circ} \mathrm{C}$ for $30 \mathrm{~s}$. Specificity of the amplification products was checked by dissociation curve analysis. No-template and no-reverse transcription controls 
Table 2. Primer sequences used for quantitative real-time PCR

\begin{tabular}{|c|c|c|c|}
\hline Gene names: gene descriptions & Gene ID & Primer sequence $\left(5^{\prime}-3^{\prime}\right)$ & $\mathrm{AL}(\mathrm{bp})$ \\
\hline \multicolumn{4}{|l|}{ PUFA synthesis } \\
\hline ELOVL5: elongation of very long-chain FA 5 & ENSSSCT00000032492 & $\begin{array}{l}\text { F: TCTATGAGTTAGTGACGGGAGTATGG } \\
\text { R: TGCGTGTGCCCTGACAGA }\end{array}$ & 79 \\
\hline FADS2: FA desaturase 2 & ENSSSCT00000014289 & $\begin{array}{l}\text { F: ATGGCATTGAGTACCAGGAAAAG } \\
\text { R: CTCAGGGACCCGATGATGTC }\end{array}$ & 64 \\
\hline FADS3: FA desaturase 3 & ENSSSCT00000014290 & $\begin{array}{l}\text { F: GCTGGTCAAGGCGTTGTGT } \\
\text { R: CCAGACTTCTTCAGGGACCTAATG }\end{array}$ & 99 \\
\hline FAS: FA synthase & AY183428 & $\begin{array}{l}\text { F: AGCCTAACTCCTCGCTGCAAT } \\
\text { R: TCCTTGGAACCGTCTGTGTTC }\end{array}$ & 196 \\
\hline G6PDH: glucose-6-dehydrogenase & ENSSSCT00000027501 & $\begin{array}{l}\text { F: GGCAACAGATACAAGAACGTGAAG } \\
\text { R: GCAGAAGACGTCCAGGATGAG }\end{array}$ & 66 \\
\hline ME: malic enzyme & X93016 & $\begin{array}{l}\text { F: TGGTGACTGATGGAGAACGTATTC } \\
\text { R: CAGGATGACAGGCAGACATTCTT }\end{array}$ & 96 \\
\hline \multicolumn{4}{|l|}{ Peroxysomal oxidation } \\
\hline ACAA1: acetyl-CoA acyltransferase 1 & ENSSSCT00000012317 & $\begin{array}{l}\text { F: AAGCAGGGCTGACAGTTGATG } \\
\text { R: AGAGGGCCTGACTTGCAAAG }\end{array}$ & 69 \\
\hline ACOX1: acyl-CoA oxidase 1 & ENSSSCT00000018723 & $\begin{array}{l}\text { F: GCGTGCCTCCAGACTAGTAGAAAT } \\
\text { R: TGGCTCGGACGAGGTCAA }\end{array}$ & 113 \\
\hline DECR2: 2,4-dienoyl CoA reductase 2 & ENSSSCT00000008752 & $\begin{array}{l}\text { F: GGCTGCCACACGGTCATC } \\
\text { R: CTTTCTAGCAGCCGTCGACACT }\end{array}$ & 60 \\
\hline EHHADH: enoyl-CoA, hydratase/3-hydroxyacyl CoA dehydrogenase & ENSSSCT00000024873 & $\begin{array}{l}\text { F: CCATGCAGAGGCTCAAGTTG } \\
\text { R: CCTCTTGCACCAGGAAGGATT }\end{array}$ & 63 \\
\hline$S C P 2$ : sterol carrier protein 2 & ENSSSCT00000004265 & $\begin{array}{l}\text { F: TCTTACAATGCTGTCCTACTTCAGATG } \\
\text { R: CTGAACAAACACTTCACTAGCCAAA }\end{array}$ & 68 \\
\hline \multicolumn{4}{|l|}{ Lipid catabolism } \\
\hline LPL: lipoprotein lipase & X62984 & $\begin{array}{l}\text { F: CCCGACGACGCAGATTTC } \\
\text { R: GGATGGCTTCCCCAATGTTA }\end{array}$ & 151 \\
\hline \multicolumn{4}{|l|}{ Incorporation of PUFA in PL } \\
\hline GNPAT: glyceronephosphate $O$-acyltransferase & ENSSSCT00000011141 & $\begin{array}{l}\text { F: GAAGAAATGCTTGGCTGTAAGACA } \\
\text { R: TTGGCAATCATTAAAGCTTTGC }\end{array}$ & 67 \\
\hline \multicolumn{4}{|l|}{ Transcription factors } \\
\hline LXRa: nuclear receptor subfamily 1 , group $\mathrm{H}$, member 3 & ENSSSCT00000014461 & $\begin{array}{l}\text { F: CTGCAACTAAATGATGCTGAGTTTG } \\
\text { R: GCCGGTCTGCAGAGAAGATG }\end{array}$ & 64 \\
\hline$L X R \beta:$ nuclear receptor subfamily 1 , group $\mathrm{H}$, member 2 & ENSSSCT00000003566 & $\begin{array}{l}\text { F: CATCCACCATTGAGATCATGCT } \\
\text { R: CCTTGCTGTAGGTGAAGTCTTTCA }\end{array}$ & 96 \\
\hline PPARa: peroxisome proliferator-activated receptor $a$ & ENSSSCT00000000007 & $\begin{array}{l}\text { F: AAGGTTGCAAGGGCTTCTTTC } \\
\text { R: CTTACAGCTCCGATCACATTTGTC }\end{array}$ & 74 \\
\hline$R X R a$ : retinoid $X$ receptor, $a$ & DQ279926.1 & $\begin{array}{l}\text { F: GGAGCTGGTGTCCAAGATGAG } \\
\text { R: CCTTGGAGTCCGGGTTGAA }\end{array}$ & 92 \\
\hline$S R E B P 1$ : sterol-regulatory element-binding protein 1 & AF102873 & $\begin{array}{l}\text { F: CGGACGGCTCACAATGC } \\
\text { R: GCAAGACGGCGGATTTATTC }\end{array}$ & 76 \\
\hline \multicolumn{4}{|l|}{ PUFA transport } \\
\hline CD36: FA translocase & NM_001044622·1 & $\begin{array}{l}\text { F: GCACAGAAAAAGTTGTCTCCAAAAAT } \\
\text { R: ATGTACACAGGTTTTCCTTCTTTGC }\end{array}$ & 124 \\
\hline FABP3: FA binding protein 3 , adipocyte & AJ416019 & $\begin{array}{l}\text { F: GCACTTACGAGAAAGAGGCATGA } \\
\text { R: GCTGAGTCCAGGAGTAGCCAATT }\end{array}$ & 74 \\
\hline LDLr: LDL receptor & ENSSSCT00000029210 & $\begin{array}{l}\text { F: AAGCACAGATGCGAAGATATCG } \\
\text { R: CCTCGAGGTTCACGCAGATC }\end{array}$ & 73 \\
\hline SCARB1: scavenger receptor class $\mathrm{B}$, member 1 & ENSSSCT00000010699 & $\begin{array}{l}\text { F: TTTTGCCCGTGCATGGA } \\
\text { R: GAAACAAGGGTGCATTGAACCT }\end{array}$ & 67 \\
\hline SLC27A1: solute carrier family 27 member 1 & ENSSSCT00000015165 & $\begin{array}{l}\text { F: GCCAGATCGGCGAGTTCTAC } \\
\text { R: ACCAACCTTCCCATCCATGTT }\end{array}$ & 71 \\
\hline SLC27A4: solute carrier family 27 member 4 & ENSSSCT00000002720 & $\begin{array}{l}\text { F: CATAAAACAGGGACTTTCAAGCTACA } \\
\text { R: TTTCACGACTGCTGGGTCAA }\end{array}$ & 72 \\
\hline VLDLr: VLDL receptor & ENSSSCT00000005763 & $\begin{array}{l}\text { F: ACCCAGCAATATCAGTTGTAAGCA } \\
\text { R: TCAAAGGTGGTGACTTGTCTCAGA }\end{array}$ & 70 \\
\hline \multicolumn{4}{|l|}{ Reference genes } \\
\hline B2M: $\beta$-2-microglobulin & DQ178123 & $\begin{array}{l}\text { F: AAACGGAAAGCCAAATTACC } \\
\text { R: ATCCACAGCGTTAGGAGTGA }\end{array}$ & 178 \\
\hline TOP2B: topoisomerase II $\beta$ & ENSSSCG00000011213 & $\begin{array}{l}\text { F: AACTGGATGATGCTAATGATGCT } \\
\text { R: TGGAAAAACTCCGTATCTGTCTC }\end{array}$ & 137 \\
\hline
\end{tabular}

ID, gene identification in Ensembl or NCBI databases; AL, amplification length; FA, fatty acid; PL, phospholipids.

were realised using $\mathrm{H}_{2} \mathrm{O}$ or no-reverse RNA as template, respectively.

Two reference genes (topoisomerase (DNA) II $\beta 180 \mathrm{kDa}$ and $\beta$-2-microglobulin) were retained as the most stable reference genes for normalisation using geNorm algorithm ${ }^{(22)}$. For each sample, a normalisation factor (NF) was calculated and used for subsequent normalisation. The normalised expression level (QrN) was calculated according to the following formula 


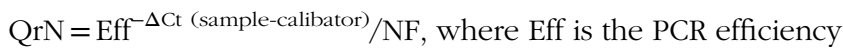
for each gene calculated from the slope of the calibration curve, Ct the quantification cycle and the calibrator is a pool of samples ${ }^{(23)}$. The lipoprotein lipase (LPL) gene was not detected in the liver, whereas the solute carrier family 27 member 1 (SLC27A1A1) and solute carrier family 27 member 4 (SLC27A4) genes were not detected in the SCAT. Finally, we have not managed to identify ELOVL2 in the three tissues studied.

\section{Statistical analyses}

All data were analysed using SAS ${ }^{\circledR} 9.4$ statistical software. Statistical comparisons were carried out by ANOVA type III (Proc GLM) with diet as the main factor. Results are presented as least squares means by diet. The standard error of the mean and the significance of the test are also presented. Multiple comparisons between groups were applied according to a $t$ test. Moreover, for animal performances, enzyme activities and results of gene expressions by RT-qPCR, orthogonal contrasts between diets were calculated to determine the effects of a supplementation with $n$-3 PUFA. Comparisons were made between the CON diet and other diets containing ALA or DHA. The effects of the increasing dose of DHA were measured with a linear contrast according to dietary DHA concentration. Linear and quadratic regression measures between the enzymatic activities or the results of PCR and the total consumption of DHA were also calculated with the DMI in covariate. Finally, correlations between enzyme (FAS, ME and G6PDH) activities and relative gene expressions were calculated as Pearson's coefficient (Proc CORR). $P$-values lower than 0.05 were considered as significant, whereas $P$-values lower than $0 \cdot 10$ were considered as a trend.

\section{Results}

\section{Growth performances and measurements at slaughter}

The FA composition of the diets did not affect $(P>0.05)$ daily feed intake, final BW, average daily gain, feed conversion ratio and SCAT and LD weights (as \% of the carcass weight). In contrast, it tended to impact liver weight $(P=0.08)$, because the mean was $2.43 \%$ for all the diets, except for the liver of pigs fed the 2ALA/1DHA diet, which weighed $2 \cdot 70 \%$ of the carcass weight (Table 3). The total fat content of SCAT and LD did not change with the diets. However, the contrasts revealed that the DHA amount of the diets increased the total fat content of the liver from $3.8 \%$ (mean of the CON and ALA diets) to $4.2 \%$ in the diets containing DHA $(P=0 \cdot 02)$.

\section{Fatty acid composition of tissues}

The quantities of ALA, EPA, DHA and total $n-3$ FA of the three tissues were affected by the FA composition of the diets $(P<0.01$; Fig. 1$)$. The quantities of EPA, DHA and total $n-3$ FA in the liver increased with a supply of DHA in the diet. On the one hand, EPA increased from 32 to $131 \mathrm{mg} / 100 \mathrm{~g}$ of liver between the CON diet and the diet with only a supply of DHA. In the same way, DHA increased from 49 to $299 \mathrm{mg} / 100 \mathrm{~g}$ of liver between these two diets. The total content of $n$-3 FA

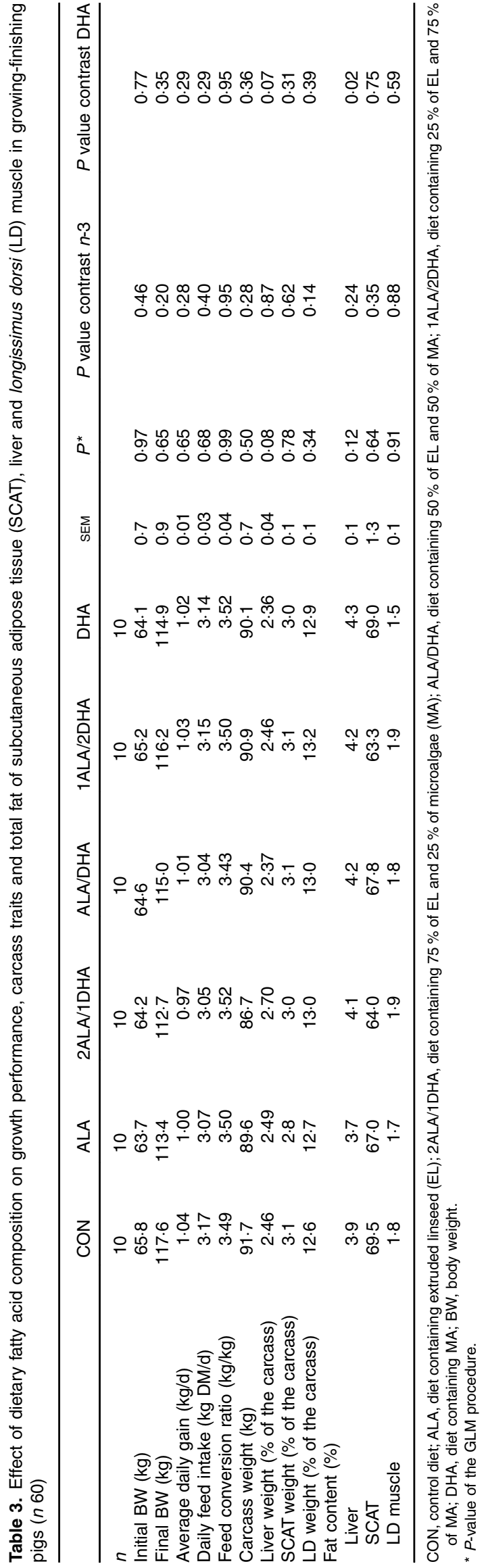



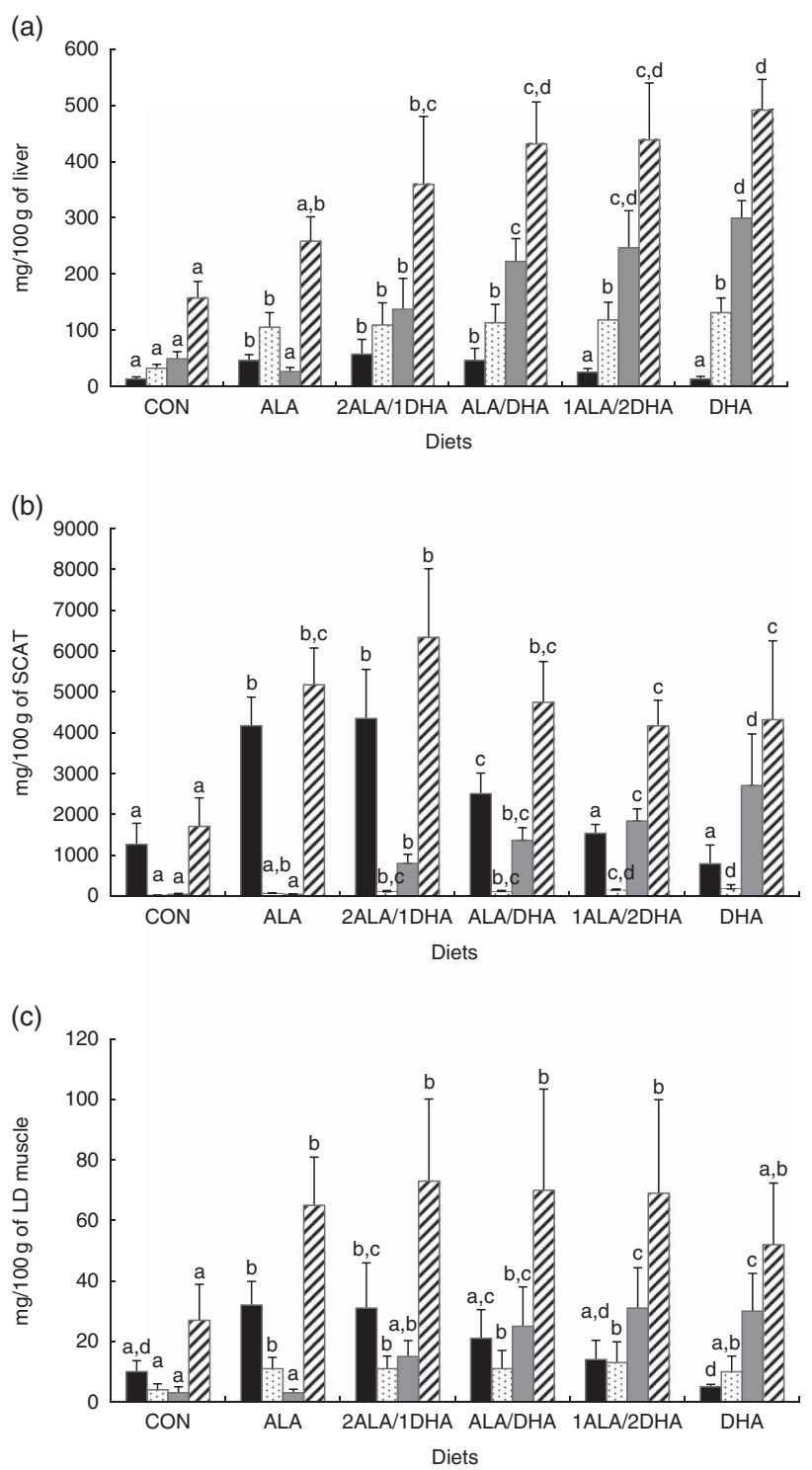

Fig. 1. Effect of dietary fatty acid (FA) composition on a-linolenic acid (ALA), EPA, DHA and $n$-3 FA quantities in the liver (a), subcutaneous adipose tissue (SCAT) (b) and longissimus dorsi (LD) muscle (c) of growing-finishing pigs. Results are least squares (LS)-mean values and standard deviations represented by vertical bars. Differences between LS means were evaluated using a $t$ test. a,b,c,d Mean values with unlike letters were significantly different $(P<0.05)$. CON, control diet; 2ALA/1DHA, diet containing $75 \%$ of $E L$ and $25 \%$ of microalgae (MA); ALA/DHA, diet containing $50 \%$ of EL and $50 \%$ of MA; $1 \mathrm{ALA} / 2 \mathrm{DHA}$, diet containing $25 \%$ of $\mathrm{EL}$ and $75 \%$ of $\mathrm{MA}$; DHA, diet containing MA. —, ALA; $: \cdot$, EPA; $\square$, DHA; $\square, n-3$ FA.

increased from 157 with the CON diet to $491 \mathrm{mg} / 100 \mathrm{~g}$ of liver with the DHA diet. On the other hand, ALA decreased in this tissue from 46 (ALA diet) to $13 \mathrm{mg} / 100 \mathrm{~g}$ of liver (DHA diet). In the SCAT, EPA and DHA increased, respectively, from 12 to $171 \mathrm{mg} / 100 \mathrm{~g}$ and from 39 to $2701 \mathrm{mg} / 100 \mathrm{~g}$ of tissue between the CON diet and the DHA diet. Quantities of ALA in the SCAT decreased from 4167 in the ALA diet group to $786 \mathrm{mg} / 100 \mathrm{~g}$ of tissue in the DHA diet group. Total $n-3$ PUFA was lower in the SCAT of animals fed the CON diet. The quantity of $n-3$ FA in this tissue increased with a supply of ALA from $1705 \mathrm{mg} / 100 \mathrm{~g}$ in the $\mathrm{CON}$ diet to $6334 \mathrm{mg} / 100 \mathrm{~g}$ in the $2 \mathrm{ALA} / 1 \mathrm{DHA}$ diet and decreased from $4745 \mathrm{mg} / 100 \mathrm{~g}$ to $4167 \mathrm{mg} / 100 \mathrm{~g}$ with a supply of DHA. As in other tissues, ALA content in the LD increased with the dietary supply of ALA, whereas DHA content in the LD increased with dietary supplementation of DHA. In this tissue, EPA and $n$ - 3 FA were lower in the CON diet group, respectively, $4 \mathrm{mg} / 100 \mathrm{~g}$ and $27 \mathrm{mg} / 100 \mathrm{~g}$, compared with other diets. Quantities of EPA and $n$-3 FA seemed to reach a maximum threshold of $66 \mathrm{mg} / 100 \mathrm{~g}$ and $11 \mathrm{mg} / 100 \mathrm{~g}$, respectively, when ALA or DHA were added to the diets. Finally, in the liver and LD muscle, EPA increased with a supply of PUFA $n-3$ as ALA and DHA compared with the CON diet. In the SCAT, EPA linearly increased with the increasing dose of PUFA $n-3$.

\section{Enzyme activities and gene expressions}

Diet composition did not affect activities of the three enzymes (ME, FAS and G6PDH) in the LD and the SCAT $(P>0.05)$. A supply of $n$-3 PUFA decreased FAS and G6PDH activity in the liver only, respectively, from 385 to 173 and from 3277 to $2577 \mathrm{nmol} / \mathrm{min}$ per $\mathrm{g}$ of tissue. In the same way, an increasing dose of DHA decreased FAS and ME activities in the liver from 352 to 173 and 855 to $671 \mathrm{nmol} / \mathrm{min}$ per g of tissue, respectively $(P<0.05)$. It also tended to decrease the FAS activity in the SCAT from 302 to $201 \mathrm{nmol} / \mathrm{min}$ per g $(P=0 \cdot 07)$ (Table 4$)$. The linear regression between enzyme activities and total ingestion of DHA showed that the activity of FAS decreased by $0 \cdot 18$ $\mathrm{NADPH} / \mathrm{min}$ per $\mathrm{g}$ produced in the liver with the supplementary ingestion of $1 \mathrm{~g}$ of DHA. In the same way, the activities of G6PDH and ME in the liver decreased, respectively, by 0.45 and $0.17 \mathrm{NADPH} / \mathrm{min}$ per $\mathrm{g}(P<0.05)$ per gram increase of DHA intake (Table 5). It means that the slope of the relationship decreased, respectively, by 17 and $18 \%$ between the activity of ME or FAS in the liver and the intake of DHA, whereas it decreased by $45 \%$ for G6PDH activity.

The results for the gene expressions of $M E, F A S, G 6 P D H$ and the genes whose expressions were modified by the diets are presented in Table 5. The intake of $n-3$ PUFA in the diets decreased the expression level of fatty acid desaturase 2 (FADS2) in the liver $(P$-value contrast $n$ - $3<0 \cdot 01)$. It also tended to decrease $F A S$ expression in the same tissue ( $P$-value contrast $n-3<0 \cdot 1)$. However, the DHA intake seems to have a stronger impact on gene expression than total $n-3$ PUFA. Indeed, the expression levels of ME, FAS and FADS2 genes decreased in the liver when DHA was introduced in the diet. The expressions of ME, FAS and FADS2 decreased, respectively, from 1.25, 1.32 and 1.99 in the ALA diet to $0.66,0.48$ and 0.55 in the diets with a mixture of ALA and DHA. Expressions of some other genes coding for transcription factors and enzymes implicated in peroxysomal oxidation and incorporation of PUFA in the phospholipids were affected by the FA composition of the diets, such as 2,4-dienoyl CoA reductase 2 (DECR2), which linearly decreased in the liver with dietary DHA supply.

The results of the linear regression analysis showed that the expressions of FADS2, FAS, ME and sterol-regulatory element binding transcription factor 1 (SREBP1) in the liver, respectively, decreased by 0.001, 0.0006, 0.0003 and 0.0005 when 1 supplementary g of DHA was ingested by pigs $(P<0.05)$. The SREBP 1 gene in the LD and glyceronephosphate $O$-acyltransferase in 
the SCAT, respectively, decreased by 0.0004 and 0.0001 $(P<0.05)$. In contrast to the enzyme activities, the slope was angled by $<1 \%$ for the expression of lipogenesis genes in the liver. However, the results of the quadratic regression showed that the expression of FADS 2 in the liver did not follow a linear decrease but followed an inverse logarithmic curve $(P=0.004)$ (Table 5, Fig. 2). In contrast, $L P L$ expression in LD increased by 0.0002 with $n-3$ inclusion in the $\operatorname{diet}(P=0.03)$. Finally, the linear regression between DHA intake and the expression of retinoid X receptor $\alpha(R X R \alpha)$ in the liver as well as $R X R \alpha$ and $D E C R 2$ in the LD was not significant, with the $P$-value being higher than 0.05 (Table 5).

Correlations between FAS, ME, G6PDH activities and their gene expressions were low ( $M E$ and $G 6 P D H)$ or almost non-existent $(F A S)$. The correlation between ME activity and its gene expression in the liver was $0.26(P=0.06)$, whereas it was $0.27(P<0.05)$ for G6PDH and $0.23(P=0.10)$ for $\mathrm{ME}$ in the SCAT (Table 6).

\section{Discussion}

\section{Effect of dietary n-3 PUFA on growth performances and lipid deposition in pigs}

We hypothesised that feeding pigs with different dietary levels of ALA and DHA will have an impact on enzyme activities and gene expressions involved in lipid metabolism, especially lipogenesis, so that FA composition of the body compartments will be modified. Unlike classical feeding schemes in farms, pigs were housed individually and fed ad libitum in our experiment. This resulted in an average feed intake of $3 \cdot 1 \mathrm{~kg} / \mathrm{d}$, which is $20 \%$ higher than current feeding practices. This feeding method allowed pigs to exhibit the possible effects of ALA and DHA on feed intake and associated lipid metabolism.

We observed that the different levels of PUFA $n-3$ did not change feed intake, growth performances and carcass traits (Table 3), because all diets were formulated to provide the same amount of net energy per kilogram of $\operatorname{diet}^{(24)}$. We have shown that FA composition of the tissues reflects partly the FA composition of the diets, in agreement with Wood et al. ${ }^{(25)}$ and Mourot \& Hermier ${ }^{(26)}$. The FA composition of the three tissues (LD, liver and SCAT) varied according to the FA composition of the diets. The total $n$ - 3 PUFA content of the liver increased linearly when intake of $n-3$ PUFA increased, whereas a maximum threshold was reached in the LD and a decrease was observed in the SCAT. It was demonstrated that lipogenic enzymes activities could be impacted by different dietary levels of energy ${ }^{(27)}$. However, as our diets were isoenergetic, only PUFA uptake was responsible for the inhibition effect of lipogenic activities in the SCAT.

\section{Effect of dietary n-3 PUFA on the enzyme activities and gene expressions involved in lipogenesis}

Pearson's coefficients between lipogenic enzyme activities and associated gene expressions were very low or almost non-existent, despite a similar effect of the supply of DHA in the diets (Table 6). As shown in some studies, enzyme activity is not 
Table 5. Relative quantity of gene expression involved in lipids metabolism in the liver, subcutaneous adipose tissue (SCAT) and longissimus dorsi (LD) muscle of growing-finishing pigs (arbitrary units) $\ddagger$

\begin{tabular}{|c|c|c|c|c|c|c|c|c|c|}
\hline \multirow[b]{2}{*}{ Tissue } & \multirow[b]{2}{*}{ Genes } & \multicolumn{3}{|c|}{ Diet } & \multirow[b]{2}{*}{ SEM } & \multirow[b]{2}{*}{$P$ value contrast $n-3$} & \multirow[b]{2}{*}{$P$ value contrast $\mathrm{DHA}$} & \multicolumn{2}{|c|}{ Effect of DHA intake } \\
\hline & & CON & ALA & DHA & & & & Linear regression & Quadratic regression \\
\hline \multicolumn{10}{|c|}{ PUFA synthesis } \\
\hline \multirow[t]{4}{*}{ Liver } & FADS2 & 2.09 & 1.99 & 0.71 & 0.23 & $<0.01$ & 0.01 & $-0.001^{\star \star *}$ & $0.000003^{\star \star *}$ \\
\hline & FAS & $1 \cdot 17$ & 1.32 & 0.66 & 0.16 & 0.09 & 0.06 & $-0.0006^{*}$ & $0.000001 \dagger$ \\
\hline & G6PDH & 1.40 & 3.05 & 1.69 & 0.67 & 0.99 & 0.28 & - & - \\
\hline & $M E$ & 0.81 & 1.25 & 0.75 & 0.08 & 0.51 & $<0.01$ & $-0.0003^{*}$ & - \\
\hline \multirow[t]{4}{*}{ SCAT } & FADS2 & $2 \cdot 37$ & $2 \cdot 23$ & 1.84 & 0.14 & 0.38 & 0.08 & $-0.0004 \dagger$ & - \\
\hline & FAS & 1.70 & 1.64 & 1.51 & 0.15 & 0.82 & 0.72 & - & - \\
\hline & G6PDH & 1.21 & $1 \cdot 13$ & 0.91 & 0.09 & 0.51 & 0.44 & - & - \\
\hline & $M E$ & 1.04 & 1.48 & $1 \cdot 15$ & 0.13 & $0 \cdot 14$ & 0.47 & - & - \\
\hline \multirow[t]{4}{*}{ LD } & FADS2 & 1.40 & 1.59 & 1.46 & 0.09 & 0.93 & 0.55 & - & - \\
\hline & FAS & 0.47 & 0.33 & 0.39 & 0.05 & 0.95 & 0.93 & - & - \\
\hline & G6PDH & 0.79 & 0.82 & 0.80 & 0.04 & 0.73 & 0.69 & - & - \\
\hline & $M E$ & 0.75 & 0.76 & 0.84 & 0.05 & 0.80 & 0.63 & - & - \\
\hline \multicolumn{10}{|c|}{ Peroxysomal oxidation } \\
\hline Liver & DECR2 & 1.09 & 1.23 & 0.94 & 0.13 & 0.42 & 0.21 & $-0.0003 \dagger$ & - \\
\hline SCAT & DECR2 & 1.94 & 1.84 & 1.84 & 0.10 & 0.92 & 0.96 & - & - \\
\hline LD & DECR2 & 1.25 & 1.74 & 1.32 & 0.08 & $0 \cdot 10$ & 0.04 & - & - \\
\hline \multicolumn{10}{|c|}{ Transcription factors and PUFA transport } \\
\hline \multirow[t]{2}{*}{ Liver } & $R X R a$ & 1.35 & 1.81 & 1.48 & 0.11 & 0.08 & 0.06 & - & - \\
\hline & SREBP1 & 1.05 & 1.73 & 0.87 & 0.12 & 0.87 & $<0.01$ & $-0.0005^{\star}$ & - \\
\hline \multirow[t]{3}{*}{ SCAT } & $L P L$ & 1.29 & 1.58 & 1.36 & $0 \cdot 11$ & $0 \cdot 17$ & 0.39 & - & - \\
\hline & $R X R a$ & 1.72 & 1.84 & 1.73 & 0.06 & 0.81 & 0.57 & - & - \\
\hline & SREBP1 & 1.61 & 1.71 & 1.47 & 0.08 & 0.98 & 0.38 & - & - \\
\hline \multirow[t]{3}{*}{ LD } & $L P L$ & 0.61 & 0.63 & 0.79 & 0.04 & 0.05 & $0 \cdot 18$ & $0.0002^{*}$ & $-0.0000006^{\star}$ \\
\hline & $R X R a$ & $1 \cdot 15$ & 1.42 & $1 \cdot 15$ & 0.04 & 0.43 & 0.07 & - & - \\
\hline & SREBP1 & 1.44 & 1.31 & 0.85 & 0.08 & 0.08 & 0.02 & $-0.0004^{\star *}$ & - \\
\hline \multicolumn{10}{|c|}{ Incorporation of PUFA in PL } \\
\hline Liver & GNPAT & 0.95 & 0.97 & 0.90 & 0.04 & 0.80 & 0.41 & - & - \\
\hline SCAT & GNPAT & $1 \cdot 13$ & 1.05 & 0.96 & 0.04 & 0.21 & 0.09 & $-0.0001 \dagger$ & - \\
\hline LD & GNPAT & 0.77 & 0.88 & 0.83 & 0.03 & 0.42 & 0.51 & - & - \\
\hline
\end{tabular}

CON, control diet; ALA, diet containing extruded linseed; DHA, diet containing microalgae; contrast $n-3$, diet CON $v$. other diets; contrast DHA, diets CON and ALA v. diets containing a supply of DHA; FADS2, fatty acid desaturase 2 ; FAS fatty acid synthase; $G 6 P D H$, glucose-6-dehydrogenase; $M E$, malic enzyme; $D E C R 2: 2,4$-dienoyl CoA reductase 2; $R X R a$, retinoid X receptor alpha; $S R E B P 1$, sterol-regulatory element binding transcription factor 1; $L P L$, lipoprotein lipase; $P$ L, phospholipid, GNPAT, glyceronephosphate $O$-acyltransterase, - , non-signilicant.

$\ddagger$ Slope of the linear regression and the quadratic regression conducted between enzyme activities and total DHA intake (g, during 2 months). 


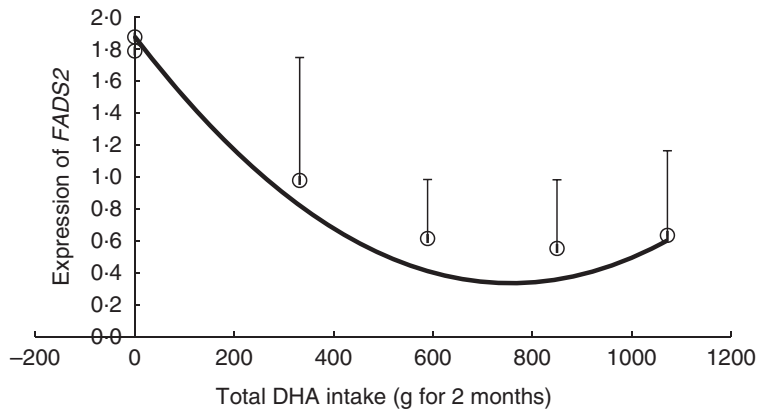

Fig. 2. Expression of the fatty acid desaturase 2 (FADS2) gene (arbitrary units) in the liver of growing-finishing pigs according to the six experimental diets. Results are least squares mean values and standard deviations. O, Quadratic regression between the expression of the FADS2 gene and the intake of DHA; , trend line of the quadratic regression.

bound with its gene expression ${ }^{(28-30)}$. Our experiment confirmed the difficulty to highlight a relationship between gene expression and the activity of its protein. This could be explained by the fact that our method to determine enzyme activity estimated a potential of activity and not the true activity of the enzyme in alive animals. Moreover, it is difficult to establish good correlations between gene expressions and enzymes activities for two other reasons. First, there exist others steps between both, which are not taken into consideration in the calculations. Second, the results of enzyme activities between the three tissues varied from 16 to 198 , whereas the dispersion of gene expression values varied from 30 to 170 according to the $\mathrm{CV}$, suggesting that a higher number of samples would be required to highlight differences between diets.

The experiment was designed to determine the effects of substituting ALA by DHA in the diets of growing-finishing pigs when they contained high levels of $n-3$ PUFA. To account for the direct effects of dietary $n-3$ PUFA on lipid metabolism, we also had a CON diet depleted in $n-3$ PUFA. In agreement with Guillevic et $a l .{ }^{(6)}$, Kouba et $a l .{ }^{(31)}$ and Corino et $a l .{ }^{(32)}$, our study showed that ME, FAS and G6PDH activities in LD muscle of growing-finishing pigs were not affected by diets rich in PUFA $n$-3. In our study and in the study of Guillevic et al. ${ }^{(6)}$, G6PDH activity in the SCAT was also not affected by a supply of PUFA $n$-3. In contrast, in our study, we showed that $n-3$ PUFA decreased FAS and G6PDH activities in the liver of pigs, but not ME. The activity of ME decreased linearly in the liver with increasing dose of ALA in the study of Guillevic et al. ${ }^{(6)}$. Enzyme activities in rabbits seem to behave in the same way as in pigs, because ME, FAS and G6PDH activities in the liver decreased with a supply of $\mathrm{EL}^{(33)}$. In contrast, the expressions of the genes involved in lipogenesis were not affected in the three tissues by a supply of $n$-3 PUFA in our experiment, except a trend for FAS to decrease in the liver. This trend is supported by the result of Dannenberger et $a l^{(34)}$, who showed that FAS expression decreased in the liver of pigs with a supply of linseed oil in the diet. According to the experiment conducted on monogastric animals, an increasing dose of $n-3$ PUFA in animal diets seems to decrease the activity of enzymes involved in lipogenesis, suggesting that the longer-chain FA decrease their activities in the liver. About the gene expression, Benitez et al. ${ }^{(9)}$ explained that PUFA down-regulate genes related to lipid synthesis contrary to SFA, because of the longer chain of PUFA than SFA.

In our experiment, when we substituted ALA by DHA, we found that FAS and ME activities and their gene expressions in the liver decreased linearly. Moreover, the FAS activity tended to decrease in the SCAT as well with a supply of DHA. According to Clarke ${ }^{(35)}$, PUFA $n-3$ as EPA or DHA from menhaden fish oil decreased the transcription of the FAS gene in the liver, confirming that the activity of FAS and its expression in the liver of our pigs decreased because of a supply of DHA in the diets. This could also be explained by the fact that gene expression is impacted by the length of the carbon chain, the number and location of double bonds of the $\mathrm{FA}^{(35)}$. This may explain why DHA, which is a longer FA than ALA, has a deeper impact on enzyme activities and gene expressions.

We showed that the activities of the enzymes and the expressions of the genes were impacted by DHA supply mainly in the liver, whereas the effects in other tissues were limited. The increasing dose of DHA in the diet induced the increase in lipid content in the liver, especially PUFA $n$-3, whereas it decreased in the SCAT and reached a threshold in the LD muscle. In addition, in our experiment, the liver contained up to $13 \%$ of DHA of total fat, whereas the SCAT and LD muscle contained $<4 \%$ of total fat as DHA. The hepatic DHA was not exported to others tissues because dietary DHA decreases VLDL secretion by the liver ${ }^{(36)}$. It was also demonstrated that a supply of DHA could inhibit the maturation of hepatic VLDL of rats ${ }^{(37)}$. These observations could also explain that the liver was the tissue in which the lipogenic activity and gene expressions were the most influenced by the amounts of $n-3$ FA or DHA in the diets. In contrast, the SCAT was less influenced by the diet composition; however, it is the major site of de novo lipogenesis after weaning ${ }^{(38)}$. Our findings therefore suggest that, at wholeanimal level, the effects of dietary DHA on lipogenesis were moderated.

\section{Effect of dietary n-3 PUFA on the gene expressions involved in fatty acid metabolism}

In this study, we showed that a DHA supply in the pig diet decreased gene expressions and enzyme activities involved in the hepatic lipogenesis. Other gene expressions involved in long-chain FA synthesis also decreased in tissues with an increasing dose of DHA in the diets, except the $L P L$ gene. The $L P L$ gene is a target gene of PPAR $\gamma$ and it can hydrolyse the lipoprotein TAG in the blood plasma to release NEFA for muscle uptake ${ }^{(39)}$. It is directly involved in the deposition of FA in intramuscular fat. The $L P L$ gene is also involved in the catabolism of FA in the LD muscle, and its expression in our experiment increased in this tissue. However, contrary to the $n$-3 FA contrast, the contrast with DHA did not reveal a significant difference of the $L P L$ gene expression between diets. According to the experiment of Luo et al. ${ }^{(40)}$, LPL expression increased with PUFA $n-3$ in the muscle of pigs, especially with increasing linseed feeding time, confirming the result of the $n-3$ PUFA contrast. Nevertheless, Wang et al. ${ }^{(41)}$ explained that $L P L$ expression increases with $\mathrm{C} 18: 1$, but decreases with C16:0. 
Table 6. Correlations between fatty acid synthase (FAS), malic enzyme (ME) and glucose-6-dehydrogenase (G6PDH) activities and their gene expressions in the subcutaneous adipose tissue (SCAT), longissimus dorsi (LD) muscle and liver of growing-finishing pigs

\begin{tabular}{|c|c|c|c|c|c|c|c|c|c|}
\hline & \multicolumn{3}{|c|}{ FAS } & \multicolumn{3}{|c|}{ ME } & \multicolumn{3}{|c|}{ G6PDH } \\
\hline & Liver & SCAT & LD & Liver & SCAT & LD & Liver & SCAT & LD \\
\hline$r$ & -0.003 & 0.06 & 0.12 & 0.26 & 0.23 & 0.13 & 0.27 & -0.03 & -0.11 \\
\hline$P$ & 0.98 & 0.66 & 0.37 & 0.06 & 0.10 & 0.31 & 0.04 & 0.81 & 0.40 \\
\hline
\end{tabular}

$r$, Pearson's coefficient of correlation.

It seems that the increased $L P L$ expression in this experiment could be due to the $n$ - 3 FA content of the diets or to the amount of $\mathrm{C} 18: 1$ of the LD muscle.

At the level of the cell nucleus, we showed that SREBP1 expression linearly decreased in the liver with a supply of DHA in the diet. SREBP1 is a transcription factor that binds to the DNA sequence of a sterol-regulatory element. It must be activated by proteolytic cleavage to be able to bind to the nuclear DNA, thereby activating the transcription of lipogenic genes such as FAS, acetyl-CoA carboxylase and stearoyl-CoA desaturase. The result regarding SREBP1 in the pig liver is in accordance with others studies, which showed that mRNA of SREBP1 decreased in the liver of pigs with supply of a DHA-rich oil extracted from algae ${ }^{(42,43)}$, which could also have an impact on the expressions of its target genes. It was also demonstrated that inactivation of SREBF1 inhibits the synthesis of HDL and $\mathrm{VLDL}^{(44)}$. We can assume that the liver will secrete less HDL and VLDL containing FA, including PUFA, according to the low transfer of DHA from the liver to the other tissues previously mentioned. We also showed that the dietary DHA decreased SREBF1 expression in the LD muscle, whereas this was not demonstrated in the semimembranosus muscle of fattening pigs receiving fish oil with a high content of $\mathrm{DHA}^{(45)}$. In addition, the FADS2 gene was also decreased by the dietary FA in our study and is in agreement with other studies ${ }^{(7,45,46)}$. FADS2 is a gene encoding $\Delta 6$-desaturases, which makes it possible to transform ALA in the endoplasmic reticulum of cells into C18:4n-3 and then $\mathrm{C} 24: 5 n-3$ into $\mathrm{C} 24: 6 n-3$. The $\mathrm{C} 24: 6 n-3 \mathrm{FA}$ is finally transformed into DHA by peroxysomal $\beta$-oxidation. One of these two desaturations or both seem to have been down-regulated by the action of DHA in order to regulate the synthesis of this FA in the liver. However, in our experiment, the amount of EPA increased in the liver with the supply of PUFA $n-3$ in the diets, which did not contain EPA. Two hypotheses could explain this observation. First, only the second $\Delta 6$-desaturase involved in PUFA synthesis was impacted by the dietary FA content, allowing the synthesis of EPA and C24:5n-3, but not C24:6n-3. Second, EPA can be derived from retroconversion of DHA, when DHA content in the tissue is high, because this possibility was demonstrated in studies on liver of rats ${ }^{(47-48)}$. In this case, both $\Delta 6$-desaturases were impacted by the diets, which could explain that PUFA $n-6$ content in our experiment decreased in the liver of pigs with an increased intake of dietary PUFA $n-3$. Indeed, the long-chain PUFA $n-6$ and $n-3$ competes with the $\Delta 6$-desaturase ${ }^{(12,50)}$. With the decrease in the expression of $F A D S 2$, we could also expect to see a decrease in FADS1 and ELOVL5. As FADS1 and
ELOVL5 were not affected by diets, we can assume that the synthesis of C24:5 was potentially feasible. Finally, if both $\Delta 6$-desaturases were impacted by the diet, the synthesis of C24: $6 n-3$ would decrease. In this case, it could partly explain that, in the peroxisome, the expressions of the genes involved in PUFA oxidation such as acetyl-CoA acyltransferase 1, acylCoA oxidase 1, DECR2, enoyl-CoA, hydratase/3-hydroxyacyl CoA dehydrogenase, sterol carrier protein 2, SLC27A1 or SLC27A4 in the liver of pigs of our study were not increased in order to oxidise $\mathrm{C} 24$ : $6 n-3$ into DHA. In contrast, the expression of $R X R \alpha$ tended to decrease quadratically in the liver and the LD muscle with increasing dose of dietary DHA. The $\operatorname{RXR} \alpha$ is a nuclear receptor that mediates the biological effect of retinoid. More precisely, it binds to the $\operatorname{PPAR} \alpha$ transcription factor and indirectly activates peroxysomal $\beta$-oxidation of the FA. As the expression of $R X R \alpha$ decreased in the LD muscle, this could explain the plateau of PUFA $n-3$ in this tissue. In the same way, even if the decrease was not linear, the intake of DHA inhibits the expression of DECR2 in the LD muscle, which encodes for a peroxysomal protein involved in the degradation of unsaturated fatty enoyl-CoA esters having $\Delta 4$ double bonds such as C24: $6 n-3$ or DHA. However, there was a plateau of EPA, an increase of DHA and no decrease of PUFA $n-3$ as in the SCAT in this tissue. Its means that the inhibition of DECR2 suppresses the oxidation of the small amount of dietary DHA introduced in the peroxisome, preventing the retroconversion of this dietary DHA into EPA.

\section{Conclusion}

In our experiment, we tested the effect of dietary $n$-3 PUFA from EL (mainly ALA) and MA (mainly DHA) on the activities and the expressions of enzyme involved in lipogenesis in the liver, SCAT and LD muscle of growing-finishing pigs. We also tested their effects on the expressions of genes involved in FA metabolism in the same tissues. The gene expressions and the activities of lipogenic enzymes such as malic enzyme, FA synthase and glucose-6-dehydrogenase in the liver decreased with an increasing dose of DHA in the diets. In contrast, gene expressions and enzyme activities of lipogenesis were unaffected by the dietary FA composition in the LD muscle and the SCAT. In the same way, DHA inhibited the expression of a gene involved in FA synthesis - namely, SREBP1 - in the liver and in the LD muscle. It also inhibited the expression of the gene encoding for the $\Delta 6$-desaturases, that is, FADS2, in the liver. Finally, MA decreased the expression of the DECR2 gene in the LD muscle, which participates in the degradation of unsaturated fatty enoyl-CoA esters having double bonds in the 
peroxisome. Thus, the PUFA oxidation in the LD muscle and their synthesis in the liver were limited with the introduction of DHA in the pigs' diet; however, this FA seems to be retroconverted into EPA in this last tissue.

\section{Acknowledgements}

The authors acknowledge the technical and temporary staff of INRA Laboratory involved in this experiment. They are gratefully thanked for their skilled assistance.

This work was supported by the National Agricultural Research Institute, but it received no specific grant from any funding agency, commercial or not-for-profit sectors.

A. D. T. formulated the research question, designed the study, carried out the study, analysed the data and wrote the article. E. L. assisted in the correction and developed the questions. J. M. designed the study and also assisted in the correction and developed the questions. A. V. was involved in the laboratory assessments and data analysis. All the authors read and approved the final version of the manuscript.

The authors declare that there are no conflicts of interest.

\section{References}

1. Lebret B \& Mourot J (1998) Caractéristiques et qualité des tissus adipeux chez le porc. Facteurs de variation non génétiques (Characteristics and quality of pig adipose tissues. Influence of rearing factors). INRA Prod Anim 11, 131-143.

2. Lavialle M \& Layé S (2010) Acides gras poly-insaturés (omega 3, omega 6) et fonctionnement du système nerveux central (Polyunsaturated fatty acids (omega 3, omega 6) and brain functions). Innovations Agronomiques 10, 25-42.

3. Kouba M \& Mourot M (1999) Effect of a high linoleic acid diet on lipogenic enzyme activities and on the composition of the lipid fraction of fat and lean tissues in the pig. Meat Sci $\mathbf{5 2}$ $39-45$.

4. Mourot J, Peiniau P \& Mounier A (1994) Effets de l'acide linoléique alimentaire sur l'activité des enzymes de la lipogenèse dans les tissus adipeux chez le porc (Effect of dietary linoleic acid on lipogenesis in adipose tissue of pigs). Reprod Nutr Dev 34, 213-220.

5. Waterman RA, Romsos DR, Tsai AC, et al. (1975) Influence of dietary sunflower oil and tallow on growth, plasma lipids and lipogenesis in rats, pigs and chicks. Proc Soc Exp Biol Med 150, 347-351.

6. Guillevic M, Kouba M \& Mourot J (2009) Effect of a linseed diet or a sunflower diet on performances, fatty acid composition, lipogenic enzyme activities and stearoyl-coa-desaturase activity in the pig. Livestock Sci 124, 288-294.

7. Duran-Montge P, Theil PK, Lauridsen C, et al. (2009) Dietary fat source affects metabolism of fatty acids in pigs as evaluated by altered expression of lipogenic genes in liver and adipose tissues. Animal 3, 535-542.

8. Meadus J, Aalhus J, Uttaro B, et al. (2011) DHA reduces triglycerides and stimulates fat metabolism in pigs. Can J Anim Sci 91, 475-521.

9. Benitez R, Nunez Y, Fernandez A, et al. (2015) Effects of dietary fat saturation on fatty acid composition and gene transcription in different tissues of iberian pigs. Meat Sci 102, $59-68$.
10. Cho HP, Nakamura MT \& Clarke SD (1999) Cloning, expression, and fatty acid regulation of the human d-5 desaturase. J Biochem Chem 274, 37335-37339.

11. Cho HP, Nakamura MT \& Clarke SD (1999) Cloning, expression, and nutritional regulation of the mammalian d- 6 desaturase. J Biol Chem 274, 471-477.

12. Smink W, Gerrits WJ, Gloaguen M, et al. (2012) Linoleic and alpha-linolenic acid as precursor and inhibitor for the synthesis of long-chain polyunsaturated fatty acids in liver and brain of growing pigs. Animal 6, 262-270.

13. Igarashi M, Ma K, Chang L, et al. (2007) Dietary n-3 PUFA deprivation for 15 weeks upregulates elongase and desaturase expression in rat liver but not brain. J Lipid Res 48, 2463-2470.

14. Sauvant D, Perez JM \& Tran G (2004) Tables of Composition and Nutritional Value of Raw Materials for Livestock. Versailles: INRA.

15. AFNOR (1982) Animal feed. Determination of water content. In $N F$ V18-109. Paris: AFNOR.

16. ISO (2008) ISO 16634-1:2008. Food products - determination of total nitrogen content by combustion according to the Dumas principle and calculation of crude protein content. Part 1: Oilseeds and animal feeding stuffs. http://www.iso.org/iso/ catalogue_detail.htm?csnumber $=46328$

17. ISO (1998) ISO 9831:1998. Animal feeding stuffs, animal products, and faeces or urine - determination of gross calorific value - bomb calorimeter method. http://www.iso.org/iso/iso_ catalogue/catalogue_tc/catalogue_detail.htm?csnumber $=17702$

18. Folch J, Lees M \& Sloane Stanley GH (1957) A simple method for the isolation and purification of total lipides from animal tissues. J Biol Chem 226, 497-509.

19. Morrison WR \& Smith LM (1964) Preparation of fatty acid methyl esters and dimethyl acetals from lipids with boron fluoride methanol. J Lipid Res 5, 600-608.

20. Bazin R \& Ferré P (2001) Assays of lipogenic enzymes. Methods Mol Biol 155, 121-127.

21. Ballester M, Cordon R \& Folch JM (2013) Dag expression: high-throughput gene expression analysis of real-time PCR data using standard curves for relative quantification. PLOS ONE 8, e80385.

22. Vandesompele J, De Preter K, Pattyn F, et al. (2002) Accurate normalization of real-time quantitative RT-PCR data by geometric averaging of multiple internal control genes. Genome Biol 3, 2-12.

23. Pfaffl MW (2001) A new mathematical model for relative quantification in real-time RT-PCR. Nucleic Acids Res 29, 2002-2007.

24. Quiniou N \& Noblet J (2012) Effect of the dietary net energy concentration on feed intake and performance of growing-finishing pigs housed individually. J Anim Sci 90 , 4362-4372.

25. Wood JD, Enser MB \& Macfie HJH (1978) Fatty acid composition of backfat in large white pigs selected for low backfat thickness. Meat Sci 2, 289-296.

26. Mourot J \& Hermier D (2001) Lipids in monogastric animal meat. Reprod Nutr Dev 41, 109-118.

27. Bee G, Messikommer R \& Gebert S (1999) Dietary fats and energy levels differently affect tissue lipogenic enzyme activity in finishing pigs. Fett/Lipid 9, 336-342.

28. Cherfaoui M (2012) La synthèse et/ou la lipoperoxydation des acides gras polyinsaturés à chaîne longue n-3 sont-elles les étapes limitantes de leur dépôt au niveau musculaire chez le bovin? (Are the synthesis and/or lipid peroxidation of long-chain $n$-3 polyunsaturated fatty acids the limiting steps of their deposition in the muscles of cattle?) PhD Thesis, University of Auvergne. 
29. Guillevic M, Ezanno H \& Mourot J (2008) La nature des acides gras influence-t-elle l'adipoconversion des préadipocytes en culture primaire chez le porcelet? (Does the nature of fatty acids influences the adipoconversion of preadipocytes in primary culture in piglets?) Nutr Clin Métab 22, S25-S53.

30. Latchman DS (1997) Transcription factors: an overview. Int J Biochem Cell Biol 29, 1305-1312.

31. Kouba M, Enser M, Whittington FM, et al. (2003) Effect of a high-linolenic acid diet on lipogenic enzyme activities, fatty acid composition, and meat quality in the growing pig. J Anim Sci 81, 1967-1979.

32. Corino C, Musella M \& Mourot J (2008) Influence of extruded linseed on growth, carcass composition, and meat quality of slaughtered pigs at one hundred ten and one hundred sixty kilograms of liveweight. J Anim Sci 86, 1850-1860.

33. Benatmane F, Kouba M, Youyou A, et al. (2011) Effect of a linseed diet on lipogenesis, fatty acid composition and stearoyl-coa-desaturase in rabbits. Animal 5, 1993-2000.

34. Dannenberger D, Nuernberg K, Nuernberg G, et al. (2014) Impact of dietary protein level and source of polyunsaturated fatty acids on lipid metabolism-related protein expression and fatty acid concentrations in porcine tissues. J Agric Food Chem 62, 12453-12461.

35. Clarke SD (1993) Regulation of fatty acid synthase gene expression: an approach for reducing fat accumulation. J Anim Sci 71, 1957-1965.

36. Gladine C, Roy NC, Rigaudiere JP, et al. (2012) Increasing intake of long-chain $n$-3 PUFA enhances lipoperoxidation and modulates hepatic gene expression in a dosedependent manner. Br J Nutr 107, 1254-1273.

37. Maitin V, Andreo U, Guo L, et al. (2014) Docosahexaenoic acid impairs the maturation of very low density lipoproteins in rat hepatic cells. J Lipid Res 55, 75-84.

38. O'Hea EK \& Leveille GA (1969) Significance of adipose tissue and liver as sites of fatty acid synthesis in the pig and the efficiency of utilization of various substrates for lipogenensis. J Nutr 99, 338-344.
39. Goldberg IJ (1996) Lipoprotein lipase and lipolysis: central roles in lipoprotein metabolism and atherogenesis. J Lipid Res 37, 693-707.

40. Luo HF, Wei HK, Huang FR, et al. (2009) The effect of linseed on intramuscular fat content and adipogenesis related genes in skeletal muscle of pigs. Lipids 44, 999-1010.

41. Wang W, Xue W, Jin B, et al. (2013) Candidate gene expression affects intramuscular fat content and fatty acid composition in pigs. I Appl Genet 54, 113-118.

42. Hsu JM, Wang PH, Liu BH, et al. (2004) The effect of dietary docosahexaenoic acid on the expression of porcine lipid metabolism-related genes. J Anim Sci 82, 683-689.

43. Liu BH, Wang YC, Kuo CF, et al. (2005) The effects of docosahexaenoic acid oil and soybean oil on the expression of lipid metabolism related mrna in pigs. AJAS 18, 1451-1456.

44. Guesnet P, Alessandri JM, Astorg P, et al. (2005) Les rôles physiologiques majeurs exercés par les acides gras polyinsaturés (agpi) (Physiological functions of polyunsaturated fatty acids). OCL 12, 333-343.

45. Duran-Montge P, Theil PK, Lauridsen C, et al. (2009) Fat metabolism is regulated by altered gene expression of lipogenic enzymes and regulatory factors in liver and adipose tissue but not in semimembranosus muscle of pigs during the fattening period. Animal 3, 1580-1590.

46. Mirshekar R, Boldaji F, Dastar B, et al. (2015) Longer consumption of flaxseed oil enhances n-3 fatty acid content of chicken meat and expression of fads2 gene. Eur J Lipid Sci Technol 117, 810-819.

47. Schlenk H, Gellerman JL \& Sand DM (1967) Retroconversion of polyunsaturated fatty acids in vivo by partial degradation and hydrogenation. Biochem Biophys Acta 137, 420-426.

48. Schlenk H, Sand DM \& Gellekman JL (1969) Retroconversion of DHA in the rat. Biochim Biophys Acta 187, 201-207.

49. Verdino B, Blank ML, Privett OS, et al. (1964) Metabolism of $4,7,10,13,16$-docosapentaenoic acid in the essential fatty acid deficient rat. J Nutr 83, 234-238.

50. Guillou H, D'Andrea S, Rioux V, et al. (2004) The surprising diversity of delta 6-desaturase substrates. Biochem Soc Trans 32, 86-87. 